\title{
Oncologic and Renal Function Outcomes After Radical Cystectomy and Ureterocutaneostomy: A Single Center Experience
}

\author{
Radikal Sistektomi ve Üreterokutonostomi Sonrası Onkolojik ve Renal Fonksiyon Sonuçları: \\ Tek Merkez Deneyimi
}

\author{
(1) Şevket Tolga Tombul1', (1) Gökhan Sönmez², (1) Abdullah Demirtaş' ${ }^{1}$ (1) Atila Tatlışen ${ }^{1}$ \\ 1Erciyes University Faculty of Medicine, Department of Urology, Kayseri, Turkiye \\ 2Kayseri City Hospital, Clinic of Urology, Kayseri, Turkiye
}

\section{What's known on the subject? and What does the study add?}

Ureterocutenoustomy is not a preferred urinary diversion after radical cystectomy. But sometimes urologists have to chose this diversion most probably due to patient related factors. We believe that this is one of the largest ureterocutenoustomy series in Turkiye and will contribute to the literature.

\begin{abstract}
Objective: It is aimed to present the long-term oncologic and nephrological follow-up results in patients who underwent radical cystectomy and ureterocutaneostomy $(\mathrm{RC}+\mathrm{UC})$ due to localized muscle-invasive bladder cancer (MIBC).

Materials and Methods: A total of 83 patients diagnosed with localized MIBC (age $\geq 70$ years or an American Society of Anesthesiologists score $\geq 3$ ), who underwent RC+UC between January 1995 and June 2013, were evaluated retrospectively. Patients who died due to postoperative early surgical complications and patients with a preoperative glomerular filtration rate $(\mathrm{GFR})<50 \mathrm{~mL} /\left(\mathrm{min} \times \mathrm{m}^{2}\right)$, a solitary kidney, another malignancy, a dialysis history, and patients without a follow-up information record were excluded.

Results: The median age of the patients was 71 years. Seventy-three (88\%) were male. Distant organ metastasis was detected in 33 patients. Thirtyone (37.3\%) patients died of causes other than cancer, 35 (42.2\%) died from cancer progression, and 17 (20.5\%) survived. Preoperatively, 38 had hydroureteronephrosis (HUN) in one or both kidneys and 6 had undergone preoperative urinary diversion. Sixty-three (75.9\%) patients had stoma stenosis, and they were followed with ureteral stents. The number of patients requiring permanent dialysis due to postrenal acute renal failure was $5(6 \%)$. A significant difference was observed between the preoperative, first- and third-year GFR levels in 52 patients having at least a 3 -year follow-up period. The change in GFR was found to be 32\% after 3 years of follow-up in these patients. The decrease in GFR was more prominent in patients with preoperative HUN.

Conclusion: RC+UC should be considered as an option in carefully selected patients in whom the risk of renal function loss is acceptable in terms of age, comorbidity, and life expectancy.
\end{abstract}

Keywords: GFR, Radical cystectomy, Ureterocutaneostomy

Öz

Amaç: Bu çalışmada, kasa invazyon gösteren lokalize mesane kanseri (KiMK) nedeniyle uygulanan radikal sistektomi ve üreterokutaneostomi (RS+ÜK) uygulanan hastaların uzun dönem onkolojik ve böbrek fonksiyonu takip sonuçlarının sunulması amaçlanmıştır.

Gereç ve Yöntem: Ocak 1995-Haziran 2013 arasında KiMK tespit edilen, 70 yaş ve üzeri veya Amerikan Anestezi Uzamanları Derneği skoru 3 ve üzeri olması nedeniyle RS+ÜK ameliyatı yapılmış 83 hastanın verileri retrospektif olarak değerlendirilmiştir. Preoperatif glomerüler filtrasyon hızı $(\mathrm{GFR})<50 \mathrm{~mL} /\left(\min \times \mathrm{m}^{2}\right)$ olan, soliter böbrekli olan, başka bir malignitesi olan, diyaliz öyküsü olanlar, takip verileri olmayan, postoperatif erken cerrahi komplikasyonlara bağlı exitus olan hastalar çalışma dışı bırakılmıştır. Hastaların demografik, onkolojik ve neforlojik verileri kaydedilmiştir.

Bulgular: Çalışmaya dahil edilen 83 hastanın ortanca yaşı 71 yıldı. Hastaların 73'ü (\%88) erkek, 10'u (\%12) ise kadındı. Otuz üç hastada uzak organ

Correspondence: Abdullah Demirtaş MD, Kayseri City Hospital, Clinic of Urology, Kayseri, Turkiye

Phone: +90 5325094494 E-mail: mesane@gmail.com ORCID-ID: orcid.org/0000-0001-9102-5518

Received: 21.03.2019

Accepted: 07.08.2019

Cite this article as: Tombul ŞT, Sönmez G, Demirtaş A, Tatlışen A. Oncologic and Renal Function Outcomes after Radical Cystectomy and Ureterocutaneostomy: A Single Center Experience. J Urol Surg 2019;6(4):314-319.

oCopyright 2019 by the Association of Urological Surgery / Journal of Urological Surgery published by Galenos Publishing House. 
metastazı tespit edildi. Otuz bir $(\% 37,3)$ hasta kanser dışı nedenlerle, $35(\% 42,2)$ hasta kanser progresyonu nedeniyle ölürken, $17(\% 20,5)$ hasta hayattaydı. Otuz sekiz hastada tek veya her iki böbrekte preoperatif hidroüreteronefroz (HUN) izlendi ve bunların 6'sına preoperatif üriner diversiyon yapılmıştı. Altmış üç $(\% 75,9)$ hastada stoma darlığı gelişti ve bu hastalar üreteral stent ile takip edildi. Takip boyunca postrenal akut böbrek yetmezliğine bağlı kalıcı diyaliz ihtiyacı olan hasta sayısı 5 (\%) idi. En az 3 yıllık takip süresi olan 52 hastanın preoperatif, 1 ve 3 . yıl GFR düzeyleri arasında istatistiksel olarak anlamlı fark olduğu tespit edildi. Ayrıca bu hastalar için 3 yıllık takip sonunda GFR değişimi \%32 olarak belirlendi. GFR düşüşü, preopertif HUN olan hastalarda daha belirgindi.

Sonuç: Yaş, komorbidite ve yaşam beklentisi yönünden renal fonksiyon kaybının göze alınabileceği, dikkatle seçilmiş hastalarda radikal sistektomi ve üreterokutaneostomi ameliyatı bir seçenek olarak akılda bulundurulmalıdır.

Anahtar Kelimeler: GFR, Radikal sistektomi, Üreterokutonostomi

\section{Introduction}

Bladder cancer is the seventh most common type of cancer among men in the world and the $11^{\text {th }}$ most common type of cancer in both genders (1) .

Radical cystectomy (RC), lymph node dissection, and urinary diversion (UD) surgery are standard treatments for localized muscle-invasive bladder cancer (MIBC) (2). There are three main types of UD surgeries performed after cystectomy. These can be classified as abdominal diversions [ureterocutaneostomy (UC), ileal conduit (IC) or colo conduit], urethral diversion [orthotopic bladder substitution (OBS) or neobladder], and recto-sigmoid diversion (ureterorectostomy) (3). The performance status, comorbidities, and age of the patient play an important role in determining the type of UD to be performed together with cystectomy. However, the debate about the age and the type of UD continues (4).

UC is defined as the simplest form of UD. It is based on the logic of anastomosis of the ureter to the abdominal wall. Short operative time and hospital stay, low metabolic complication rates, and low morbidity due to intact bowel integrity are the advantages of UC compared with diversions using an ileal segment $(5,6)$. However, the risk of stoma stenosis and increased susceptibility to urinary infection in the region where the ureter is opened to the skin in the late postoperative period are the disadvantages of this technique compared with abdominal diversions using a bowel segment $(7,8)$.

This retrospective study aimed to present the long-term oncologic and renal function outcomes in patients who had RC and UC due to localized MIBC.

\section{Materials and Methods}

Uro-oncology files of 109 patients diagnosed with localized MIBC [age $\geq 70$ years or an American Society of Anesthesiologists (ASA) score of $\geq 3$ ], who underwent RC and UC between January 1995 and June 2013 in Erciyes University, Urology Clinic, were evaluated retrospectively. 83 patients were included in the study after excluding patients who died due to early postoperative complications $(n=6)$, patients with a preoperative glomerular filtration rate (GFR) of $<50 \mathrm{~mL} /\left(\min \times \mathrm{m}^{2}\right)(\mathrm{n}=4)$, with a solitary kidney $(n=2)$, with another known malignancy $(n=2)$, with a history of dialysis for any reason $(n=2)$, and patients with incomplete records in terms of oncologic and renal function outcomes $(n=10)$. Patient age, body mass index (BMI), gender, ASA score, histopathological results, tumor-node- metastasis staging system stage, follow-up duration until death, progression of the disease, preoperative, first- and third-year GFR levels, need for dialysis, and status of stoma stenosis were evaluated.

$\mathrm{RC}$ and UC were performed with a median incision below the umbilicus in all patients in the supine position and under general anesthesia. Following standard RC and lymph node dissection, both ureters were released above the iliac crossover level. Frozen-section analysis was performed from the distal ends of the bilateral ureter. After the frozen-section surgical analysis was reported as negative for malignancy, both ureters were spatulated from the lateral sides. The stoma was opened to the side of the dominant hand of the patient on the anterior wall of the abdomen (right side for right-handers and left side for left-handers). For the right-sided stoma, the left ureter was pushed to the right side by aligning to the inferior mesenteric artery below the mesenterium. Both ureters were anastomosed to each other from their lateral sides in such a way that the left ureter stayed at the top. A V-shaped incision was made from the lateral edge of the rectus muscle in the right lower quadrant. A fascia was opened from this incision. Both ureters were moved to the skin from the fascia. The ureters were anastomosed to a V-shaped incision with 4.0 polyglactin sutures. After anastomosis, $6 \mathrm{Fr}$ double-J stents (DJSs) were placed in both ureters. Depending on patient characteristics, the DJSs were removed 6-12 weeks after procedure. During follow-up, the patients were evaluated for stoma stenosis and/or tumor recurrence with abdominal ultrasonography for every three months and computed tomography for every six months. After removal of the DJS, abdominal ultrasonography was performed weekly for the first two weeks, then every 2 weeks for the next month and monthly upto the 6th month and every 3 months thereafter. Patients, who had increased or newly diagnosed hydroureteronephrosis (HUN) in the kidneys and/or elevated serum creatinine levels during the follow-up, 
were accepted as having postrenal acute renal failure (ARF) and stoma stenosis (stricture). DJSs of these patients were replaced at regular intervals throughout their lifetime. Local recurrence or distant metastasis were assessed as progression. GFR was calculated with the simplified modification of diet in renal disease (MDRD) equation (186 $\times$ serum creatinine $\mathrm{e}^{-1.154} \times$ age $^{-0.203}$ $\times$ gender coefficient $\times$ race coefficient).

Before RC and UC, written informed consents were taken from all patients. The study was designed in accordance with the Declaration of Helsinki, and approved by the local ethics committee (approval no: 2019/445).

\section{Statistical Analysis}

Statistical analysis of the numerical data showing normal distribution was performed using the independent samples t-test. The repeated measures ANOVA was used for dependent multiple groups. The post-hoc analysis of this test was performed using the Bonferroni correction. The chi-square test was applied for analyzing categorical data. Kaplan-Meier survival analysis was used for survival evaluation. Normally distributed numerical data were expressed as mean ( \pm standard deviation), and nonnormal numerical data were expressed as median (min-max). A $p$ value of less than 0.05 was considered significant.

\section{Results}

The mean age of the 83 patients was $70.22 \pm 5.99$ years. 24 patients were younger than 70 years but they had ASA scores $>2.73$. Seventy-three $(88 \%)$ of the all patients were male, and $10(12 \%)$ were female. Thirty-three (39.8\%) patients had developed distant organ metastasis during follow-up. Also, 31 (37.3\%) patients died of non-cancer-related causes. 4 of the non-cancer deaths were related with acute or chronic renal failure. Thirty-five (42.2\%) patients died of cancer progression, and $17(20.5 \%)$ survived. The median duration of follow-up was 42 (5-192) months. The demographic and oncologic follow-up data are summarized in Table 1. The Kaplan-Meier analysis of overall survival is shown in Figure 1.

During preoperative staging with abdominal imaging, it was detected that 38 patients had HUN at least in one kidney. Six of them had preoperative UD (nephrostomy or DJS). A total of $63(75.9 \%)$ patients had stoma stenosis. The median time elapsed between DJS removal and stoma stenosis diagnosis was 3 (1-12) weeks and the follow-up of these patients continued with ureteral stents replaced at regular intervals. The median stent replacement interval in these patients was 14 weeks (826). During the follow-up, the number of patients requiring permanent dialysis due to postrenal ARF was 5 (6\%).

A significant difference was observed in preoperative, first- and third-year GFR levels in 52 patients having at least a 3-year follow-up period. The renal functions deteriorated over time in these patients (Figure 2). In addition, the change in GFR in these patients was 32\% after 3 years of follow-up. These patients were divided into two groups: those without preoperative HUN (group $1, \mathrm{n}=25$ ) and those with preoperative HUN (group 2,

\begin{tabular}{|l|l|}
\hline \multicolumn{2}{|l|}{ Table 1. Demographic data and oncological results of patients } \\
\hline Number of patients (n) & 83 \\
\hline Age (year) & $70.22 \pm 5.99^{*}$ \\
\hline BMI $\left(\mathrm{kg} / \mathrm{m}^{2}\right)$ & $25.6 \pm 4.07^{*}$ \\
\hline Gender & \\
Male & $73 / 83$ \\
Female & $10 / 83$ \\
\hline Smoking history & \\
Male & $65 / 73(89 \%)$ \\
Female & $1 / 10(10 \%)$ \\
\hline ASA Score & $3.5(2-5)$ \\
\hline Pathology & \\
TCC & $73(87.9 \%)$ \\
Out of TCC & $10(12.1 \%)$ \\
\hline TNM stage & \\
Stage 1 & $7 / 83$ \\
Stage 2 & $46 / 83$ \\
Stage 3 & $20 / 83$ \\
Stage 4 & $10 / 83$ \\
\hline Disease free survival (month) & $36(0-192)^{* *}$ \\
\hline Overall survival (month) & $42(5-192)^{* *}$ \\
\hline 5-year survival & $32.5 \%$ \\
\hline Progression & $38 / 83(45.8 \%)$ \\
\hline *: Mean \pm standard deviation \\
**: Median (min-max) & \\
BMI: Body mass index, TCC: Transitional cell carcinoma, ASA: American Society of \\
Anesthesiologist, TNM: Tumor-node-metastasis staging system \\
\hline
\end{tabular}

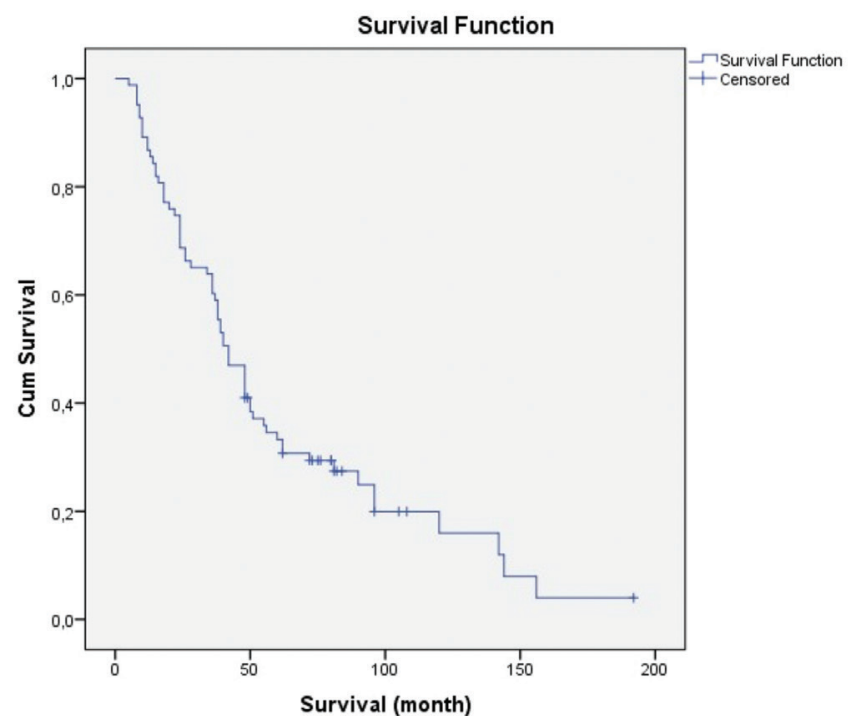

Figure 1. Overall postoperative survival chart based on the Kaplan-Meier analysis 
$n=27)$. No significant difference between the groups was found in terms of preoperative basal GFR levels and decrease in GFR at the end of first year, but the GFR decrease at the end of the third postoperative year was significantly higher in group 2 $(p=0.001)$ (Table 2).

There were 20 patients without stoma stenosis. Six of them died within the first 3 years postoperatively. Out of 6 patients, 4 died from cancer. Median basal, postoperative $1^{\text {st }}$ and $3^{\text {rd }}$ year GFRs in 14 patients without stoma stenosis were 81.01 (74.52-117.49), $79.22(74.32-104.45)$ and $77.85(64.53-80.21) \mathrm{mL} /\left(\min \times \mathrm{m}^{2}\right)$, respectively. The decrease in GFR was statistically significant $(p=0.000002)$. However, this decrease would not be clinically meaningful because there were only 14 patients. The changes in GFR in patients without stoma stenosis are shown in Table 3 and Figure 2.

\section{Discussion}

Radical cystectomy, lymph node dissection, and UD are standard treatments for MIBC. The type of UD method to be selected

Table 2. Demographic data and renal function outcomes of all patients with at least 3 years of follow-up

\begin{tabular}{|l|l|l|l|l|}
\hline & $\begin{array}{l}\text { Overall } \\
(\mathbf{n = 5 2 )}\end{array}$ & $\begin{array}{l}\text { Group 1 } \\
(\mathbf{n = 2 5 )}\end{array}$ & $\begin{array}{l}\text { Group 2 } \\
(\mathbf{n = 2 7})\end{array}$ & $\mathbf{p}$ \\
\hline Age (year) & $69.6 \pm 5.19$ & $70.6+4.2$ & $68.6+5.8$ & 0.15 \\
\hline BMI $\left(\mathrm{kg} / \mathrm{m}^{2}\right)$ & $25.86 \pm 4.32$ & $25.1+5.1$ & $26.6+3.4$ & 0.21 \\
\hline $\begin{array}{l}\text { Preop basal } \\
\text { GFR } \\
{\left[\mathrm{mL} /\left(\text { min'm }^{2}\right]\right.}\end{array}$ & $70.68 \pm 18.47$ & $69.8+18.5$ & $71.4+18.7$ & 0.76 \\
\hline $\begin{array}{l}\text { GFR at first } \\
\text { year }\end{array}$ & $53.96 \pm 18.48$ & $57.71 \pm 20.05$ & $50.48 \pm 16.51$ & 0.161 \\
\hline $\begin{array}{l}\text { GFR at third } \\
\text { year }\end{array}$ & $47.82 \pm 19.38$ & $56.55 \pm 17.79$ & $39.74 \pm 17.43$ & 0.001 \\
\hline Stricture rate & & $16 / 25$ & $22 / 27$ & 0.16 \\
\hline
\end{tabular}

Normally distributed numerical data are expressed as mean + standard deviation, BMI: Body mass index, GFR: Glomerular filtration rate

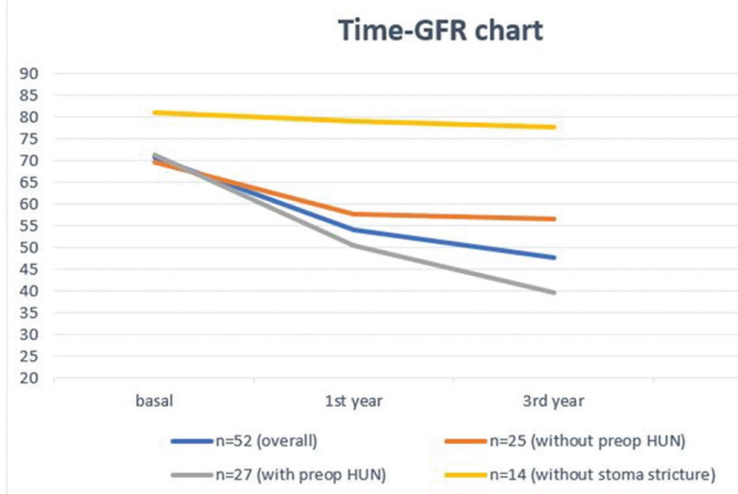

Figure 2. Evaluation of renal functions of patients having a follow-up of 3 years or more depends on the status of the patient and surgical team experience. It may be grouped as abdominal, urethral, and ureterosigmoidal diversions (4). Previous studies showed that the advantages of the UC technique compared with other diversion methods were shorter operative time and length of hospital stay, less hemorrhage, and fewer bowel complications $(5,6,7)$. In our institution, orthotopic sigmoid neobladder is the frequently chosen UD treatment for young patients with acceptable comorbidity levels and having longer life expectancy. However patients with severe comorbid conditions or advanced age and those having a relatively low life expectancy are commonly treated by UC. The purpose is to decrease the metabolic and surgical complications and bowel-induced comorbidities. In this regard, the present study included patients with localized MIBC having additional comorbidities who were older than 70 years of age and/or had an ASA score of 3 or higher. The male-to-female ratio in this study was approximately 7:1. This situation might be due to the low number of patients included in the study and the large number of exclusion criteria. One of the main pathologic types of bladder cancer is transitional cell carcinoma (TCC) (90\%). Cancers having squamous differentiation, small cell cancers, micropapillary urothelial cancers, and adenocarcinomas are examples of variants of TCC (9). Moreover, $88 \%$ of the histopathological results obtained from RC specimens in this study showed TCC and approximately $12 \%$ were other variant pathologies, in accordance with the literature.

The overall survival rate was 42 months (5-192), and the 5 -year survival rate was $32.5 \%$ in this study. According to the Surveillance, Epidemiology, and End Results (SEER) data published in 2012, the 5-year survival for localized MIBC was $47 \%$ (10). A lower 5-year survival rate in the present study when compared to the SEER data could be explained by the inclusion of patients with advanced age or high ASA scores. In their retrospective study including 224 patients with a median age of 79.2 years and ASA score of 3 or higher who underwent $R C$ and UD, Wuethrich et al. (11) reported that the overall survival was 47, 11 and 90 months for patients having IC $(n=178)$, UC $(n=11)$, and OBS $(n=35)$. However, their UC group consisted of patients older (median age 83.8 years) than ours.

Table 3. Demographic data and renal function outcomes of patients without stoma stricture and with at least 3 years of follow-up

\begin{tabular}{|l|l|}
\hline \#patients & 14 \\
\hline Age $($ year $)$ & $67.85 \pm 5.97$ \\
\hline BMI $\left(\mathrm{kg} / \mathrm{m}^{2}\right)$ & $26.21 \pm 4.69$ \\
\hline Preop basal GFR $\left[\mathrm{mL} /\left(\mathrm{min}^{\prime} \mathrm{m}^{2}\right]\right.$ & $81.01(74.52-117.49)$ \\
\hline GFR at first year & $79.22(74.32-104.45)$ \\
\hline GFR at third year & $77.85(64.53-80.21)$ \\
\hline GFR: Glomerular filtration rate, BMI: Body mass index \\
\hline
\end{tabular}


The stoma stricture that may occur in UC is one of the most important disadvantages of this UD method (7). The stricture development rate may be higher than $50 \%$ in some studies. It has been reported that palliative diversion was best initially attempted with indwelling ureteral stents because of this complication $(12,13,14)$. In their study published in 2016, Hatakeyama et al. (15) compared three different diversion methods (UC, IC, and neobladder). In this study, the need for postoperative ureteral stent was highest in the UC group (70\%) and UC diversion method was reported to be a risk factor for the development of stage-3 chronic kidney disease (CKD). According to the results of the study, $10(21 \%)$ of 47 patients who underwent abdominal diversion (UC or IC) had stage-3 CKD preoperatively; $13(28 \%)$ patients were added to the stage-3 CKD group in the fifth postoperative year, and this number increased to 23 (49\%). In the present study, similar results were obtained in terms of postoperative ureteral stent requirement and many patients $(75.6 \%)$ were followed up with ureteral stents throughout their lives. However, in terms of dialysis need, only $5(6 \%)$ of 83 patients required permanent dialysis. It is believed that this difference may be due to regarding renal failure as need for permanent dialysis instead of stage-3 CKD.

Creatinine levels have been used as the indicator of renal function in most of the previously published studies $(16,17,18,19)$. However, GFR levels calculated with the simplified MDRD equation was used as a renal function indicator in the present study because many factors, such as age, gender, muscle mass, and hydration status, might affect the creatinine level, leading to incorrect results.

In the present study, preoperative, first and third year GFR levels in the 52 patients with at least a 3-year follow-up period were compared. The patients were divided into two groups: patients having HUN preoperatively in one or both kidneys due to tumor invasion (group 1) and patients without HUN (group 2). The groups were homogeneous in terms of age, BMI, and preop basal GFR values. When these two groups were compared, no significant difference was found between the changes in preoperative and postoperative first-year GFR However, the change in the third-year postoperative GFR value was found to be significantly different between the groups. Also, deterioration in GFR levels in patients having renal dilatation was even higher. These results suggested that the presence of preoperative hydronephrosis might lead to a more severe GFR reduction in the long term. A study examining the change in renal functions in patients undergoing RC and UD surgery showed that the loss of renal function was most prominent within the first year, followed by a gradual and continuous decline in renal function (20). However, the patients included in this study consisted of patients who were administered IC and neobladder, rather than patients treated with UC as a diversion method. In addition, approximately one third of the patients included in the present study were reported to have stage-3
CKD preoperatively. Hatakeyama et al. (15) followed the renal functions of 115 patients who underwent UD after RC for 5 years and showed a significant reduction in GFR value at the end of 5 years in all patients who underwent $\mathrm{RC}$ regardless of the type of UD. When they compared the continent (neobladder) and incontinent diversion (IC and UC) techniques, they found no significant difference between the groups in terms of 5-year GFR decrease rates In the study by Hatakeyama et al. (15), the 5 -year GFR decline rate was calculated as 15\%. In the literature, GFR change has been reported to be $10 \%-25 \%$ in a 5 -year follow-up period after $\operatorname{RC}(21,22,23,24)$. In the present study, this rate was found to be $32 \%$, which was higher than in the literature. This difference could be explained by the fact that only UC-treated patients were included in the present study, while different types of diversion were included in other studies.

\section{Study Limitations}

The present study had some limitations. The Charlson Comorbidity index, which is believed to provide more accurate results in perioperative and postoperative risk assessments, could not be used because of the retrospective nature of the study. Pyelonephritis, which is another important UC complication, and infection frequency were not evaluated due to lack of data. In addition, this study had only one arm. Comparison with another UD type could not be done while evaluating renal functions.

\section{Conclusion}

$\mathrm{RC}$ and UC may be considered an option in carefully selected patients in whom the risk of renal function loss is acceptable in terms of age, comorbidity, and life expectancy. However, problems related to ureteral stent requirement and loss of renal function in the postoperative period should be discussed with the patient, and surgical procedure should be decided together with the patient. Comparative studies covering all UD types with longer follow-up are required to resolve the debate on the type of UD to be preferred.

\section{Ethics}

Ethics Committee Approval: The study was designed in accordance with the Declaration of Helsinki, and approved by the local ethics committee (approval no: 2019/445).

Informed Consent: Written informed consents were taken from all patients.

Peer-review: Externally peer-reviewed.

\section{Authorship Contributions}

Concept: Ş.T.T., G.S., A.D., Design: Ş.T.T., G.S., A.D., Data Collection or Processing: S..T.T., G.S., Analysis or Interpretation: G.S., A.D., A.T., Literature Search: Ş.T.T., G.S., Writing: Ş.T.T., G.S. 
Conflict of Interest: No conflict of interest was declared by the authors.

Financial Disclosure: The authors declared that this study received no financial support.

\section{References}

1. Ferlay J, Steliarova-Foucher E, Lortet-Tieulent J, Rosso S, Coebergh JW, Comber H, Forman D, Bray F. Cancer incidence and mortality patterns in Europe: estimates for 40 countries in 2012. Eur J Cancer 2013;49:1374-403.

2. Stein JP, Lieskovsky $G$, Cote $R$, Groshen $S$, Feng AC, Boyd $S$, Skinner $E_{1}$ Bochner B, Thangathurai D, Mikhail M, Raghavan D, Skinner DG. Radical cystectomy in the treatment of invasive bladder cancer: Long-term results in 1,054 patients. J Clin Oncol 2001;19:666-675.

3. Miller DC, Montie JE, Wei JT. The impact of co-morbid disease on cancer control and survival following radical cystectomy. J Urol 2003;169:105-109.

4. Stenzl A. Bladder substitution. Curr Opin Urol 1999;9:241-245.

5. Longo N, Imbimbo C, Fusco F, Ficarra V, Mangiapia F, Di Lorenzo G, Creta M, Imperatore $V$, Mirone V. Complications and quality of life in elderly patients with several comorbidities undergoing cutaneous ureterostomy with single stoma or ileal conduit after radical cystectomy. BJU Int 2016;118:521-526.

6. Yoshimura K, Maekawa S, Ichioka K, Terada N, Matsuta $Y$, Okubo K, Arai Y. Tubeless cutaneous ureterostomy: the Toyoda method revisited. J Urol 2001;165:785-788

7. Kilciler M, Bedir S, Erdemir F, Zeybek N, Erten K, Ozgok Y. Comparison of ileal conduit and transureteroureterostomy with ureterocutaneostomy urinary diversion. Urol Int 2006;77:245-250.

8. Berger $\mathrm{I}$, Wehrberger $\mathrm{C}$, Ponholzer $\mathrm{A}$, Wolfgang $\mathrm{M}$, Martini $\mathrm{T}$, Breinl E, Dunzinger M, Hofbauer J, Holtl W, Jeschke K, Krause SF, Kugler W, Rauchenwald M, Pauer W, Pycha A, Madersbacher S. Impact of the use of bowel for urinary diversion on perioperative complications and 90-day mortality in patients aged 75 years or older. Urol Int 2015;94:394-400.

9. Humphrey PA, Moch H, Cubilla AL, Ulbright TM, Reuter VE. The 2016 WHO Classification of Tumours of the Urinary System and Male Genital OrgansPart B: Prostate and Bladder Tumours. Eur Urol 2016;70:106-119.

10. Howlader N, Noone AM, Krapcho M, Neyman N, Aminou R, Waldron W, Altekruse SF, Kosary CL, Ruhl J, Tatalovich Z, Cho H, Mariotto A, Eisner MP, Lewis DR, Chen HS, Feuer EJ, Cronin KA (eds). SEER Cancer Statistics Review, 1975-2009 (Vintage 2009 Populations), National Cancer Institute. Bethesda, MD, https://seer.cancer.gov/csr/1975_2009_pops09/, based on November 2011 SEER data submission, posted to the SEER web site, April 2012.
11. Wuethrich PY, Vidal A, Burkhard FC. There is a place for radical cystectomy and urinary diversion, including orthotopic bladder substitution, in patients aged 75 and older: Results of a retrospective observational analysis from a high-volume center. Urol Oncol 2016;34:58.e19-27.

12. Deliveliotis C, Papatsoris A, Chrisofos M, Dellis A, Liakouras C, Skolarikos A. Urinary diversion in high-risk elderly patients: modified cutaneous ureterostomy or ileal conduit? Urology 2005;66:299-304.

13. Kozacıoğlu $Z$, Değirmenci $T$, Günlüsoy $B$, Ceylan $Y$, Minareci $S$. Ureterocutaneostomy: for whom and when? Turk J Urol 2013;39:143-146.

14. MacGregor PS, Montie JE, Straffon RA. Cutaneous ureterostomy as palliative diversion in adults with malignancy. Urology 1987;30:31-34.

15. Hatakeyama $S$, Koie $T$, Narita $T$, Hosogoe $S$, Yamamoto $H$, Tobisawa $Y_{1}$ Yoneyama T, Yoneyama T, Hashimoto Y, Ohyama C. Renal Function Outcomes and Risk Factors for Risk Factors for Stage 3B Chronic Kidney Disease after Urinary Diversion in Patients with Muscle Invasive Bladder Cancer. PLoS One 2016;22;11:e0149544.

16. Shimko MS, Tollefson MK, Umbreit EC, Farmer SA, Blute ML, Frank I. Longterm complications of conduit urinary diversion. J Urol 2011;185:562-567.

17. Madersbacher S, Schmidt J, Eberle JM, Thoeny HC, Burkhard F, Hochreiter W, Studer UE. Long-term outcome of ileal conduit diversion. J Urol 2003;169:985-990.

18. Hautmann RE, Volkmer BG, Schumacher MC, Gschwend JE, Studer UE. Long term results of standard procedures in urology: the ileal neobladder. World J Urol 2006;24:305-314.

19. Yang WJ, Cho KS, Rha KH, Lee HY, Chung BH, Hong SJ, Yang SC, Choi YD. Long-term effects of ileal conduit urinary diversion on upper urinary tract in bladder cancer. Urology 2006;68:324-327.

20. Makino K, Nakagawa T, Kanatani A, Kawai T, Taguchi S, Otsuka M, Matsumoto A, Miyazaki $H_{1}$ Fujimura $T$, Fukuhara $H$, Kume $H$, Homma Y. Biphasic decline in renal function after radical cystectomy with urinary diversion. Int J Clin Oncol 2017;22:359-365.

21. Jin XD, Roethlisberger $S$, Burkhard FC, Birkhaeuser F, Thoeny HC, Studer UE. Long-term renal function after urinary diversion by ileal conduit ororthotopic ileal bladder substitution. Eur Urol 2012;61:491-497.

22. Eisenberg MS, Thompson RH, Frank I, Kim SP, Cotter KJ, Tollefson MK, Kaushik D, Thapa P, Tarrell R, Boorjian SA. Long-term renal function outcomes after radical cystectomy. J Urol 2014;191:619-625.

23. Osawa T, Shinohara N, Maruyama S, Oba K, Abe T, Maru S, Takada N, Sazawa A, Nonomura K. Long-term renal function outcomes in bladder cancer after radical cystectomy. Urol J 2013;10:784-789.

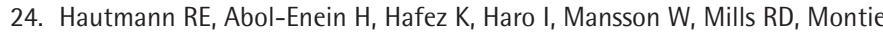
JD, Sagalowsky Al, Stein JP, Stenzl A, Studer UE, Volkmer BG. Urinary diversion. Urology 2007;69:17-49. 